\title{
Analisis Kinerja Perusahaan Sebelum Dan Sesudah Initial Public offering (IP0) Di Bursa Efek Indonesia (BEI) (Studi Kasus Pada Perusahaan Non Keuangan yang IPO Di Bursa Efek Indonesia Pada Tahun 2012 Dan 2013)
}

\author{
Teti Yuliarni \\ Akuntansi Politeknik Negeri Padang \\ teti.y@yahoo.com \\ Ulfi Maryati \\ Akuntansi Politeknik Negeri Padang \\ Email : ulfimaryati@gmail.com \\ Hidayatul Ihsan \\ Akuntansi Politeknik Negeri Padang \\ Email : ihsanm@gmail.com
}

\begin{abstract}
ABSTRAK
Penelitian ini bertujuan untuk mengetahui perbedaan Kinerja Perusahaan Sebelum dan Setelah Initial Public Offering di Bursa Efek Indonesia. Variabel yang digunakan dalam penelitian ini adalah ROA (Return on Assets), OCF (Operating Cash Flow), SG (Sales Growth ), TATO (Total Asset Turn Over ), CFRS (Cash Flow Return on Sales), dan CFNI (Cash Flow to Net Income). Sampel penelitian ini terdiri dari 34 perusahaan dengan metode purposive sampling yaitu perusahaan non keuangan yang terdaftar di Bursa Efek Indonesia (BEI) dengan periode IPO tahun 2012-2013. Teknik Analisa yang digunakan adalah metode analisis uji beda (paired t test) menggunakan software IBM SPSS versi 20. Hasil penelitian menunjukkan bahwa (1) untuk rasio ROA, SG dan TATO terdapat perbedaan kinerja yang signifikan pada perusahaan sebelum dan sesudah IPO (2) sedangkan untuk rasio OCF, CFRS dan CFNI tidak terdapat perbedaan yang signifikan pada perusahaan sebelum dan sesudah IPO.
\end{abstract}

Kata kunci: Return on Assets, Operating Cash Flow, Sales Growth, Total Asset Turn Over, Cash Flow Return on Sales dan Cash Flow to Net Income

ABSTRACT

This research aims to know the difference of the company before and after initial public offering at the indonesian stock exchange. The variables in this research are ROA (Return on Assets), OCF (Operating Cash Flow), SG (Sales Growth), TATO (Total Asset Turn Over), CFRS (Cash Flow Return on Sales), and CFNI (Cash Flow to Net Income). The sample of this research consist of 34 companies with purposive sampling method which is non financial company listed on the indonesian stock Exchange in IPO period 2012 - 2013. Analysis technique used is the method of analysis test different ( paired $t$ test) uses software ibm spss version 20. The results showed that (1) To the ratio of roa, sg and a tato there was a gap in the performance of which is significant at the company before and after ipo. (2) While to the ratio of ocf, cfrs and cfni there is no significant difference on corporations before and after ipo.

Keywords: Return on Assets, Operating Cash Flow, Sales Growth, Total Assets Turn Over, Cash Flow Return on Sales and Cash Flow to Net Income

\section{Pendahuluan}

Perusahaan didirikan dengan harapan untuk mampu bertahan dalam kelangsungan usahanya serta berkembang dengan pesat untuk jangka waktu yang panjang. Namun dengan berjalannya waktu, persaingan usaha semakin meningkat, sehingga diperlukan strategi-strategi untuk membuat perusahaan bertahan dan memenangkan persaingan 
bisnis yang semakin ketat. Dalam melaksanakan strategi tersebut perusahaan dihadapi dengan kendala yang cukup banyak. Salah satu diantaranya adalah kesulitan dalam mendapatkan pendanaan. Seiring dengan hal tersebut, pasar modal hadir untuk menjawab keluhan para pengusaha yang terkendala dalam mendapatkan dana untuk mengembangkan bisnisnya.

Undang-Undang Republik Indonesia Nomor 8 tahun 1995 menyatakan bahwa pasar modal adalah pihak yang menyelenggarakan dan menyediakan sistem dan atau sarana untuk mempertemukan penawaran jual dan beli efek pihak- pihak lain dengan tujuan memperdagangkan efek di antara mereka. Pasar modal memiliki peran penting dalam dunia usaha saat ini dimana menjembatani antara investor atau pihak yang memiliki kelebihan dana dengan pihak yang membutuhkan dana atau pengusaha, hal ini dikarenakan pasar modal menjalankan fungsi ekonomi dan keuangan. Fungsi ekonomi dari pasar modal adalah menyediakan fasilitas untuk memindahkan dana dari pihak lenders ke borrowers, dengan menginvestasikan kelebihan dana yang dimiliki. Sedangkan fungsi keuangan dilakukan dengan menyediakan dana yang diperlukan oleh para borrowers dan para lenders tanpa harus terlibat langsung dalam kepemilikan aktiva riil yang diperlukan dalam investasi tersebut (Husnan, 2005).

Mendapatkan dana di pasar modal dapat dilakukan dengan menjual saham perusahaan. Sebagaimana yang dijelaskan oleh Gumanti (2007) dalam Ikhsan (2011), bahwa dalam perkembangannya, bila perusahaan menjadi lebih besar dan semakin membutuhkan tambahan modal untuk memenuhi peningkatan operasionalnya, maka menjual saham merupakan salah satu pilihan, sehingga hal tersebut pastinya akan mempengaruhi kinerja keuangan perusahaan. Penjualan saham perusahaan hanya dapat dilakukan oleh perusahaan publik. Sebuah perusahaan dikatakan telah menjadi perusahaan publik apabila perusahaan tersebut telah melakukan proses Initial Public Offering (IPO). Yang dimaksud dengan perusahaan publik adalah perusahaan yang menjual sebagian sahamnya kepada masyarakat, untuk dapat dimiliki oleh masyarakat. Setelah menjadi perusahaan yang Initial Public Offering (IPO) atau lebih dikenal dengango public diharapkan suatu perusahaan memiliki peningkatan kinerja kearah yang lebih baik, disamping mereka telah memiliki modal yang cukup untuk meningkatkan kinerja perusahaannya.

Kinerja perusahaan dapat diartikan sebagai gambaran mengenai tingkat pencapaian pelaksanaan suatu kegiatan/program/kebijakan dalam mewujudkan sasaran, tujuan, misi dan visi organisasi yang tertuang dalam skema strategis (strategic \&planning) suatu organisasi (Bastian (2001) dalam Ikhsan, 2011). Kinerja perusahaan yang terdaftar di Bursa Efek Indonesia (BEI) secara mudah dapat dikontrol oleh pihak yang ingin menanamkan modal (investor)melalui laporan keuangan (annual report). Dimana, setiap perusahaan yang terdaftar akan mempublis laporan keuangan di BEI. Sehingga, investor dapat mempertimbangkan berbagai kriteria dalam memilih perusahaan untuk dijadikan sarana berinvestasi, salah satunya dengan melihat kinerja dari perusahaan melalui laporan keuangannya.

Laporan keuangan memiliki arti penting yang digunakan sebagai informasi dalam menilai kinerja perusahaan, sehingga disyaratkan bahwa laporan keuangan haruslah mencerminkan keadaan perusahaan yang sebenarnya pada kurun waktu tertentu, sehingga pengambilan keputusan yang berkaitan dengan perusahaan tersebut menjadi tepat. Menilai apakah kinerja suatu perusahaan itu bagus atau tidak, perlu dilakukan analisis atau pengukuran terhadap kinerjanya. Salah satu cara melakukan pengukuran kinerja adalah dengan melakukan analisis rasio. Namun perlu diketahui bahwa dalam melakukan analisis rasio untuk setiap sektor perusahaan yang terdaftar sebagai 
perusahaan yang IPO tidak bisa disamakan perhitungannya antara sektor keuangan dengan non keuangan. Karena untuk sektor keuangan penilaian kinerjanya dihitung dengan menggunakan rasio tersendiri. Sehingga perlakukan untuk menilai kinerja perusahaan sektor keuangan dengan non keuangan tidak bisa disamakan.

Menurut Ikhsan (2011), pengujian terhadap kinerja operasi perusahaan setelah IPO menarik untuk dilakukan, karena ada bukti yang konsisten di pasar modal bahwa praktik manajemen laba (earning management) pada periode sebelum go public adalah umum dilakukan oleh perusahaan. Berbagai hasil penelitian terdahulu menyatakan bahwa pada umumnya kinerja perusahaan pasca IPO menurun akibat adanya manajemen yang memperbaiki kinerja keuangan sebelum IPO, sehingga adanya perbedaan kinerja pada perusahaan sebelum dan setelah IPO. Maka Penelitian ini menguji kembali hasil penelitian yang telah pernah dilakukan sehubungan dengan kinerja perusahaan sebelum dan sesudah IPO. Penelitian ini difokuskan hanya pada perusahaan non keuangan yang terdaftar di Bursa Efek Indonesia untuk periode tahun 2012 dan 2013.

\section{KINERJA PERUSAHAAN}

Kinerja dalam sebuah organisasi merupakan salah satu unsur yang tidak dapat dipisahkan dalam suatu lembaga organisasi, baik itu lembaga pemerintahan maupun lembaga swasta. Kinerja berasal dari kata Job Performance atau Actual Performance yang merupakan prestasi kerja atau prestasi sesungguhnya yang dicapai seseorang.Sehingga dapat disimpulkan bahwa kinerja adalah kemampuan perusahaan dalam melaksanakan kebijakan dan prosedur perusahaan yang merupakan kualifikasi dari efisiensi dan efektivitas dalam pengoperasian bisnis selama periode akuntansi tertentu.Sehingga untuk mengetahui seberapa besar pencapaiannya perlu dilakukan pengukuran kinerja. Pengukuran kinerja merupakan suatu yang telah dicapai oleh organisasi dalam kurun waktu tertentu, baik yang terkait dengan input, proces, output, outcome, benefit maupun impact. Tujuan dan manfaat dilakukan pengukuran kerja ialah sebagai berikut:

1) Memberikan dasar sebagai pengukuran mutu prestasi hasil pelaksanaan kegiatan suatu perusahaan.

2) Memberikan motivasi bagi manajemen perusahaan seirama dengan kebijaksanaan yang digariskan.

Beberapa kegunaan dan manfaat hasil pengukuran kinerja menurut Riva'i dan Basri (2005) dalam Ayun (2011) yaitu:

a) Performance Improvement: berbicara mengenai umpan balik atas kinerja yang bermanfaat bagi karyawan, manajer, supervisor, dan spesialis SDM (Sumber Daya Manusia) dalam bentuk kegiatan yang tepat untuk memperbaiki kinerja pada waktu yang akan datang.

b) Compensation Adjustment: penilaian kinerja membantu dalam pengambilan keputusan siapa yang seharusnya menerima kenaikan pembayaran dalam bentuk upah, bonus ataupun bentuk lainnya yang didasarkan pada suatu sistem tertentu.

c) Placement Decision: kegiatan promosi, atau demosi jabatan dapat didasarkan pada kinerja masa lalu dan bersifat antisipatif, seperti dalam bentuk penghargaan terhadap karyawan yang memiliki hasil kinerja baik pada tugas-tugas sebelumnya.

d) Training and Development Needs: kinerja yang buruk mengindikasikan sebuah kebutuhan untuk melakukan pelatihan kembali sehingga setiap karyawan hendaknya selalu memiliki kemampuan untuk mengembangkan diri agar sesuai dengan tuntutan jabatan saat ini. 
e) Career Planing and Development: umpan balik kinerja sangat membantu dalam proses pengambilan keputusan utamanya tentang karir spesifik dari karyawan, sebagai tahapan untuk pengembangan diri karyawan tersebut.

f) Staffing Process Deficiencies: baik buruknya kinerja berimplikasi dalam hal kekuatan dan kelemahan dalam prosedur penempatan di departemen SDM.

g) Informational Inaccuracies: kinerja yang buruk dapat mengindikasikan adanya kesalahan dalam informasi analisis pekerjaan, perencanaan SDM, atau hal lain dari sistem manajemen SDM. Hal demikian akan mengarah pada ketidaktepatan dalam keputusan mempekerjakan karyawan, pelatihan dan keputusan konseling.

h) Job Design Error: kinerja yang buruk mungkin sebagai suatu gejala dari rancangan pekerjaan yang salah atau kurang tepat. Melalui penilaian kinerja dapat didiagnosis kesalahan-kesalahan tersebut.

\section{LAPORAN KEUANGAN SEBAGAI DASAR PENGUKURAN KINERJA PERUSAHAAN}

Laporan keuangan yang disusun dan disajikan kepada semua pihak yang berkepentingan dengan eksistensi suatu perusahaan pada hakekatnya merupakan alat komunikasi. Artinya laporan keuangan itu adalah suatu alat yang digunakan untuk mengkomunikasikan informasi keuangan dari suatu perusahaan dan kegiatankegiatannya kepada mereka yang berkepentingan dengan perusahaan tersebut. Sehingga laporan keuangan dijadikan sebagai dasar untuk melakukan pengukuran kinerja perusahaan. Ada banyak cara untuk mengukur kinerja suatu perusahaan. Salah satu pengukuran yang cukup baik adalah dengan menggunakan rasio-rasio kinerja operasi (operating performance) dan aliran kas (cash Flow). Penilaian kinerja perusahaan dapat diketahui melalui perhitungan rasio keuangan dari semua laporan keuangan yang disajikan perusahaan. Namun demikian, umumnya ukuran yang lazim dipakai dikategorikan kedalam 5 kelompok utama, yaitu (a) rasio keuntungan, (b) rasio aktivitas, (c) rasio leverage, (d) rasio liquiditas, (e)rasio pertumbuhan. Sebagai bagian dari alat penilaian kinerja perusahaan terutama perusahaan industri non keuangan, operating performancedapat digunakan sebagai alat penilaian kinerja perusahaan. Rasio operating performance mencakup rasio operating return on asset, operating cash flow to total asset, sales growth, dan total asset turn over. Selain itu penilaian kinerja perusahaan dapat dilakukan juga dengan menggunakan analisis rasio aliran kas.

Menurut Fahmi (2014) metode yang telah ditetapkan diatas dapat diterapkan dalam menganalisis kinerja keuangan melalui tahap-tahap sebagai berikut:

1. Melakukan review terhadap data laporan keuangan

Review dilakukan dengan tujuan agar laporan keuangan yang sudah di buat tersebut sesuai dengan penerapan kaidah-kaidah yang berlaku dalam dunia akuntansi, sehingga dengan demikian hasil laporan keuangan tersebut dapat dipertanggungjawabkan.

2. Melakukan perhitungan

Perhitungan disesuaikan dengan kondisi dan permasalahan yang sedang di lakukan sehingga hasil dari perhitungan akan memberikan suatu kesimpulan sesuai dengan analisis yang diinginkan.

3. Melakukan perbandingan terhadap hasil hitungan yang telah diperoleh.

Hasil perhitungan akan dibandingkan dengan hasil hitungan dari berbagai perusahaan lainnya. Metode yang digunakan dalam melakukan perbandingan ini ada dua macam yaitu:

a. Time series analysis yaitu membandingkan secara antar waktu atau antar periode, dengan tujuan itu nantinya akan terlihat secara grafik. 
b. Cross sectional approach yaitu melakukan perbandingan terhadap hasil hitungan rasio-rasio yang telah dilakukan antara satu perusahaan dan perusahaan yang lainnya dalam ruang lingkup yang sejenis yang dilakukan secara bersamaan. Hasil penggunaan kedua metode ini diharapkan nantinya akan dapat dibuat satu kesimpulan yang menyatakan posisi perusahaan tersebut berada dalam kondisi sangat baik, baik, normal, tidal baik, dan sangat tidak baik.

4. Melakukan penafsiran (interpretation) terhadap berbagai permasalahan yang ditemukan.

Tahapan ini analisis melihat kinerja keuangan perusahaan adalah setelah melakukan ketiga tahap tersebut selanjutnya dilakukan penafsiran untuk melihat apa-apa saja permasalahan dan kendala yang di alami oleh perusahaan tersebut.

5. Mencari dan memberikan pemecahan masalah (solution) terhadap berbagai permasalahan yang ditemukan.

Pada tahap terakhir ini setelah ditemukan berbagai permasalahan yang dihadapi maka dicarikan solusi guna memberikan suatu input atau masukan agar apa yang menjadi kendala dan hambatan selama ini bisa terselesaikan.

Sebelum melakukan langkah-langkah tersebut tentunya perlu diketahui terlebih dahulu apa saja rasio-rasio yang akan digunakan dalam menganalisis kinerja keuangan suatu perusahaan.

\section{HUBUNGAN ANTARA KINERJA PERUSAHAAN DANGAN INITIAL PUBLIC OFFERING (IPO)}

Penilaian kinerja perusahaan setelah menjadi perusahaan publik juga penting dilakukan sebab apabila kinerja perusahaan setelah menjadi perusahaan publik kurang baik atau jelek, maka akan berpengaruh pada harga saham yang beredar di pasar sekunder atau bursa efek. Perusahaan publik dituntut untuk selalu meningkatkan kinerjanya secara terus menerus, agar para investor atau pemegang saham aktif dalam memperdagangkan sahamnya di pasar modal, dan pada akhirnya harga dari saham perusahaan yang bersangkutan bisa bersaing secara kompetitif sehingga saham tersebut bisa dikategorikan menjadi saham yang blue chip.

Dari uraian diatas maka hipotesis dalam penelitian ini dirumuskan sebagai berikut:

Ha1 : terdapat perbedaan kinerja operasi perusahaan sebelum dan sesudah Initial Public Offering terkait rasio keuangan Return on Asset

Ha2 : terdapat perbedaan kinerja operasi perusahaan sebelum dan sesudah Initial Public Offering terkait rasio keuangan Operating Cash Flow.

Ha3 : terdapat perbedaan kinerja operasi perusahaan sebelum dan sesudah Initial Public Offering terkait rasio keuangan Sales Growth.

Ha4 : terdapat perbedaan kinerja operasi perusahaan sebelum dan sesudah Initial Public Offering terkait rasio keuangan Total Asset Turn Over.

Ha5 : terdapat perbedaan kinerja operasi perusahaan sebelum dan sesudah Initial Public Offering terkait rasio keuangan Cash Flow Return on Sales.

Ha6 : terdapat perbedaan kinerja operasi perusahaan sebelum dan sesudah Initial Public Offering terkait rasio keuangan Cash Flow to Net Income.

\section{METODE}

Populasi Penelitian

Populasi yang digunakan dalam penelitian ini adalah perusahaan yang ikut serta dalam Initial Public Offering (IPO). Sedangkan untuk sampel penelitian adalah perusahaan 
yang terdaftar di Bursa Efek Indonesia yang IPO pada tahun 2012-2013. Metode pemilihan sampel dalam penelitian ini diambil secara purposive sampling, yaitu pengambilan sampel dari suatu populasi dengan tujuan tertentu, tujuan yang dimaksud agar ukuran sampel yang diambil dapat mewakili seluruh populasi, dimana sampel harus memenuhi kriteria tertentu, diantaranya:

1. Perusahaaan non keuangan yang melakukan Initial Public Offerings (IPO) tahun 2012 dan 2013.

2. Tersedianya laporan keuangan untuk satu tahun sebelum dan dua tahun setelah IPO.

Tabel 1

Prosedur Pemilihan Sampel

\begin{tabular}{|l|c|}
\hline \multicolumn{1}{|c|}{ Kriteria Sampel } & Jumlah \\
\hline Perusahaan terdaftar di BEI pada tahun 2012-2013 & 52 \\
\hline Perusahaan yang terdaftar di BEI periode 2012 - 2013 sektor keuangan & $(8)$ \\
\hline $\begin{array}{l}\text { Perusahaan yang tidak memiliki laporan keuangan setelah diaudit untuk periode satu tahun sebelum IPO dan } \\
\text { dua tahun setelah IPO }\end{array}$ & $(10)$ \\
\hline Jumlah Sampel & 34 \\
\hline
\end{tabular}

Berikut ini daftar perusahaan yang menjadi sampel dalam penelitian ini :

Tabel2

Sampel Penelitian

\begin{tabular}{|c|c|c|c|}
\hline No. & Kode & Nama & Tanggal Pencatatan \\
\hline 1 & WIIM & Wismilak Inti Makmur Tbk & Desember 18, 2012 \\
\hline 2 & ASSA & Adi Sarana Armada Tbk & Nopember 12, 2012 \\
\hline 3 & BSSR & Baramulti Suksessarana Tbk & Nopember 08, 2012 \\
\hline 4 & NELY & Pelayaran Nelly Dwi Putri Tbk & Oktober 11, 2012 \\
\hline 5 & PALM & Provident Agro Tbk & Oktober 08, 2012 \\
\hline 6 & IBST & Inti Bangun Sejahtera Tbk & Agustus 31, 2012 \\
\hline 7 & GAMA & Gading Development Tbk & Juli 11,2012 \\
\hline 8 & ALTO & Tri Banyan Tirta Tbk & Juli 10, 2012 \\
\hline 9 & MSKY & MNC Sky Vision Tbk & Juli 09, 2012 \\
\hline 10 & TOBA & Toba Bara Sejahtra Tbk & Juli 06, 2012 \\
\hline 11 & TRIS & Trisula International Tbk & Juni 28, 2012 \\
\hline 12 & RANC & Supra Boga Lestari Tbk & Juni 07, 2012 \\
\hline 13 & BEST & Bekasi Fajar Industrial Estate Tbk & April 10, 2012 \\
\hline 14 & ESSA & Surya Esa Perkasa Tbk & Februari 01, 2012 \\
\hline 15 & TELE & TipHone Mobile Indonesia Tbk & Januari 12, 2012 \\
\hline 16 & SIDO & PT Industri Jamu dan Farmasi Sido Muncul Tbk & Desember 18, 2013 \\
\hline 17 & SSMS & PT Sawit Sumbermas Sarana Tbk. & Desember 12, 2013 \\
\hline 18 & LEAD & PT Logindo Samudramakmur Tbk. & Desember 11, 2013 \\
\hline 19 & $\mathrm{KRAH}$ & PT Grand Kartech Tbk & Nopember 08, 2013 \\
\hline 20 & APII & PT Arita Prima Indonesia Tbk. & Oktober 29, 2013 \\
\hline 21 & SILO & PT Siloam International H0spitals Tbk. & September 12, 2013 \\
\hline 22 & ECII & PT Electronic City Indonesia Tbk. & Juli 03, 2013 \\
\hline
\end{tabular}




\begin{tabular}{|r|r|l|r|}
23 & SMBR & PT Semen Baturaja (Persero) Tbk & Juni 28, 2013 \\
\hline 24 & NRCA & PT Nusa Raya Cipta Tbk. & Juni 27, 2013 \\
\hline 25 & SRTG & PT Saratoga Investama Sedaya Tbk. & Juni 26, 2013 \\
\hline 26 & ACST & PT Acset Indonusa Tbk. & Juni 24, 2013 \\
\hline 27 & DSNG & PT Dharma Satya Nusantara Tbk. & Juni 14,2013 \\
\hline 28 & MPMX & PT Mitra Pinasthika Mustika Tbk. 29,2013 \\
\hline 29 & ANJT & PT Austindo Nusantara Jaya Tbk. & Mei 08, 2013 \\
\hline 30 & DYAN & PT Dyandra Media International Tbk. & Maret 25, 2013 \\
\hline 31 & ISSP & PT Steel Pipe Industry of Indonesia Tbk TBK & Februari 22, 2013 \\
\hline 32 & TPMA & Trans Power Marine Tbk & Februari 20, 2013 \\
\hline 33 & SAME & Sarana Meditama Metropolitan Tbk & Januari 11, 2013 \\
\hline 34 & BBRM & Pelayaran Nasional Bina Buana Raya Tbk & Januari 09, 2013 \\
\hline
\end{tabular}

Sumber : Data Sekunder Diolah, 2016

\section{OPERATING VARIABEL}

1) Operating Return on Asset (ROA) diukur sebagai rasio laba operasi terhadap total asset. Tingkat pengembalian operasi terhadap asset mencerminkan suatu pengukurnan efisiensi dalam pengggunaan asset. Hal ini berarti bahwa keadaan tersebut menunjukkan seberapa efisien asset yang ada di perusahaan digunakan dalam menghasilkan laba operasi.

$$
\text { ROA }=\frac{\text { Laba Bersih }}{\text { Total aktiva }} \times 100 \%
$$

2) Operating Cash Flow (OCF) mencerminkan kinerja operasi yang baik karena aliran kas operasi merupakan komponen utama dalam perhitungan nilai sekarang bersih (net present value) yang digunakan oleh perusahaan. Investor secara langsung atau tidak langsung lebih banyak menekankan analisisnya terhadap kemampuan perusahaan dalam memperoleh kas bersih dari aktivitas operasi.

$$
\mathrm{OCF}=\frac{\text { jumlah arus kas operasi }}{\text { kewajiban lancar }}
$$

3) Sales Growth (GS) atau pertumbuhan penjualan menunjukkan kemampuan perusahaan dalam meningkatkan kinerja operasinya. Artinya, jika rasio pertumbuhan penjualan meningkat, perusahaan secara ekonomis akan mampu meningkatkan pendapatan operasinya.

Keterangan:

$$
\mathrm{g}=\frac{\mathrm{S} 1-\mathrm{S} 0}{\mathrm{~S} 0} \times 100 \%
$$

$\mathrm{g}=$ growth sales rate (tingkat pertumbuhan penjualan)

$\mathrm{S} 1=$ total current sales (total penjualan selama periode berjalan)

$\mathrm{S} 0=$ total sales for last period (total penjualan periode yang lalu)

4) Total Asset Turn Over (tingkat perputaran total asset) diukur dengan rasio penjualan terhadap total asset perusahaan. Semakin tinggi rasio perputaran total asset berarti semakin tinggi kemampuan perusahaan dalam mengoptimalkan asset-asset yang dimiliki untuk menghasilkan 
penjualan. Perusahaan dikatakan mengalami peningkatan efisiensi penggunaan assetnya jika rasio perputaran total asset dari waktu ke waktu mengalami peningkatan.

$$
\text { tingkat perputaran total asset }=\frac{\text { Penjualan }}{\text { Aktiva Usaha }}
$$

5) Cash Flow Return on Sales digunakan untuk mengetahui sejauh mana perusahaan melakukan investasi pada sumber-sumber dana yang produktif.

$$
\text { Cash Flow Return on Sales }=\frac{\text { operating cash flow }}{\text { net sales }(\text { revenue })}
$$

6) Cash Flow to Net Income mengukur kemampuan perusahaan untuk menghasilkan kas pada saat sekarang maupun dimasa depan. Melalui rasio ini dapat diketahui seberapa besar kas dari aktifitas operasi dibandingkan dengan laba bersih yang diperoleh.

$$
\text { Cash Flow to Net Income }=\frac{\text { operating cash flow }}{\text { net income }}
$$

\section{METODE ANALISIS DATA}

Analisis data yang dilakukan dengan menggunakan uji t tes yang bertujuan untuk mengetahui perbedaan kinerja pada perusahaan non keuangan yang terdaftar di BEI sebelum dan sesudah perusahaan melakukan IPO dari tahun 2012 -2013 dan diolah dengan menggunaka program Statistical Package For Science (SPSS).

\section{HASIL DAN PEMBAHASAN}

Berdasarkan hasil pengolahan data maka dapat dilihat perkembangan kinerja perusahaan yang diukur dengan rasio operating return on asset, operating cash flow, sales growth, total asset turn over, cash flow to net income dan cash flow return on sales pada 34 perusahaan yang melakukan IPO di Bursa Efek Indonesia tahun 2012-2013. Untuk lebih jelasnya dapat dilihat pada tabel 3 berikut :

Tabel 3

Perkembangan kinerja perusahaan yang terdaftar di Bursa Efek Indonesia sebelum dan sesudah Initial Public Offering

\begin{tabular}{lrr}
\hline & \multirow{2}{*}{ Rasio } & \multicolumn{2}{c}{ Mean } \\
& sebelum & sesudah \\
\hline ROA & 11.725800 & 4.050700 \\
OCF & 0.314176 & 0.323118 \\
SG & 40.065400 & 4.306900 \\
TATO & 1.038235 & 0.728647 \\
CFRS & 0.151029 & 0.092882 \\
CFNI & 1.185794 & 1.121412 \\
\hline
\end{tabular}


Berdasarkan tabel diatas dapat dilihat bahwa seluruh rasio keuangan yang digunakan untuk mengukur kinerja perusahaan rata-rata lebih baik sebelum perusahaan melakukan IPO. Hal ini mengindikasikan bahwa terdapat perbedaan kinerja perusahaan sebelum dan sesudah melakukan IPO, selain itu juga hasil penelitian ini membuktikan bahwa kinerja perusahaan sesudah melakukan IPO cenderung menurun.

Sebagaimana terlihat ROA mengalami penurunan sesudah pasca IPO. Hal ini menunjukkan secara rata-rata adanya penurunan kinerja perusahaan dalam mengoptimalkan aktiva perusahaan untuk menghasilkan laba. Karena ROA yang tinggi menyatakan bahwa perusahaan mampu mengolah aktiva secara efisien untuk menghasilkan laba. Sebaliknya ROA yang rendah menyatakan aktiva yang terdapat didalam perusahaan belum dikelola secara efisien untuk menghasilkan laba.

Sebagaimana OCF menghitung kemampuan arus kas operasi dalam membayar kewajiban lancar. Rasio ini diperoleh dengan membagi arus kas operasi dengan kewajiban lancar. OCF yang berada dibawah 1 berarti terdapat kemungkinan perusahaan tidak mampu membayar kewajiban lancar, tanpa menggunakan arus kas dan aktivitas lain. Berdasarkan perhitungan diatas dikatakan secara rata-rata nilai OCF dibawah 1 yang menyatakan perusahaan belum mampu membayar kewajiban lancar, tanpa menggunakan arus kas.

Jika dilihat dari Hasil uji SG diatas mencerminkan manifestasi keberhasilan investasi periode masa lalu dan dapat dijadikan sebagai prediksi pertumbuhan masa yang akan datang. Pertumbuhan penjualan juga merupakan indikator permintaan dan daya saing perusahaan dalam suatu industri. Pertumbuhan penjualan adalah kenaikan jumlah penjualan dari tahun ke tahun atau waktu ke waktu. Pertumbuhan penjualan tinggi, maka akan mencerminkan pendapatan meningkat seperti yang dialami oleh perusahaan setelah IPO.

Namun jika dilihatdari kinerja TATO meningkat sesudah IPO untuk uji t TATO. Perbedaan dari kinerja perusahaan berdasarkan rasio TATO mengalami peningkatan yang signifikan. Total Assets Turnover merupakan rasio yang menunjukkan tingkat efisiensi penggunaan keseluruhan aktiva perusahaan dalam menghasilkan volume penjualan tertentu. Semakin tinggi nilai rasio menunjukkan aktiva dapat lebih cepat berputar dan meraih laba dan semakin efisien penggunaan keseluruhan aktiva dalam menghasilkan penjualan. Hasil uji ini diperkuat oleh hasil penelitian Ikhsan (2011) yang menyatakan bahwa terdapat perbedaan kinerja yang signifikan antara sebelum dan sesudah go public pada rasio TATO. Senada dengan hasil penelitian oleh Susilowati dan Amanah (2013) Perbedaan Kinerja Keuangan Sebelum dan Sesudah Go Public Pada Perusahaan Non-Keuangan di Bursa Efek Indonesia, dimana terdapat perbedaan yang signifikan pada kinerja keuangan di perusahaan non keuangan setelah go public pada rasio TATO.

Hal yang berbeda jika ditinjau dari segi hasil uji CFRS yang menunjukkan bahwa perusahaan kurang jeli dalam berinvestasi pada sumber-sumber dana yang produktif sehingga aliran kas yang ada dalam operasi perusahaan kurang berjalan dengan lancar. Rasio ini berguna untuk mengukur kemampuan perusahaan untuk mengubah setiap rupiah penjualan menjadi kas atau mengukur persentase arus kas per rupiah penjualan. Semakin tinggi rasio ini semakin baik kinerja dari perusahaan. Hal ini diperkuat oleh Nasir dan 
Pamungkas (2005) Analisis kinerja perusahaan keuangan perusahaan non perbankan sebelum dan sesudah menjadi perusahaan publik, yang menyatakan bahwa kinerja perusahaan tidak memiliki perbedaan signifikan sebelum dan sesudah menjadi perusahaan publik.

Sedangkan untuk hasil uji CFNI menunjukkan bahwa arus kas dari aktivitas operasi dengan laba bersih untuk menilai seberapa besar arus kas yang diperoleh dari aktivitas operasi bila dibandingkan dengan laba bersihnya. Hasilnya Analisis kinerja perusahaan keuangan perusahaan non perbankan sebelum dan sesudah menjadi perusahaan publik, tidak memiliki perbedaan signifikan sebelum dan sesudah menjadi perusahaan publik untuk pengujian menggunakan rasio CFNI.

Hal ini didukung melalui hasil penelitian SPSS dengan nilai sig lebih besar dari pada 0,05. Artinya kinerja keuangan untuk rasio OCF, CFRS dan CFNI tidak memiliki perbedaan yang signifikan untuk dua tahun sesudah IPO dibandingkan dengan satu tahun sebelum IPO. Hasil ini konsisten dengan hasil penelitian Nasir dan Pamungkas (2005) bahwa kinerja perusahaan sebelum dan sesudah melakukan IPO tidak terdapat perbedaan signifikan. Hanya pada sebagian rasio yang digunakan terdapat perbedaan yang signifikan namun perbedaan tersebut hanya bersifat sesaat dan tidak konsisten. Hal yang senada dikemukan oleh Susilowati dan Amanah (2013) bahwa kinerja keuangan sebelum dan sesudah go public perusahaan non keuangan di BEI untuk satu tahun sebelum dan sesudah IPO tidak menunjukkan adanya perbedaaan yang signifikan. Dimana hasil penelitian tersebut sama-sama menegaskan bahwa kinerja perusahaan sebelum dan sesudah melakukan IPO tidak mengalami perbedaan yang signifikan. Namun perbedaannya dengan penelitian terdahulu adalah uji rasio yang digunakan, objek penelitian dan rentang waktu penelitian yang digunakan.

Sedangkan untuk rasio keuangan ROA, SG dan TATO diindikasikan bahwa terdapat perbedaan yang signifikan dari kinerja perusahaan sebelum dan sesudah melakukan IPO, dimana menunjukan adanya perbedaan yang bernilai negatif cukup signifikan sehingga akan memberikan dampak terhadap kinerja pada periode selanjutnya. Hal ini diperkuat oleh Ikhsan (2011) rasio keuangan yang digunakan untuk mengukur kinerja perusahaan rata-rata lebih baik sebelum perusahaan melakukan IPO. Hal yang senada dinyatakan oleh Susilowati dan Amanah (2013) bahwa untuk rasio yang sama ROA dan TATO menunjukan adanya perbedaan yang signifikan pada kinerja perusahaan sebelum dan sesudah melakukan IPO. Hasil dari penelitian tersebut sama-sama menyatakan adanya perbedaan kinerja yang signifikan, pada objek penelitian perusahaan non keuangan, namun hanya berbeda pada rentang waktu penelitiannya dengan menggunaka uji yang berbeda. Berikut tabel ringkasan hasil uji t untuk satu tahun sebelum dan dua tahun sesudah IPO: 
Tabel 4

Ringkasan hasil uji t untuk satu tahun sebelum IPO dan dua tahun sesudah IPO untuk seluruh sampel

\begin{tabular}{|c|c|c|c|c|}
\hline $\begin{array}{c}\text { Rasio } \\
\text { Keuangan }\end{array}$ & t hitung & $\mathbf{t}$ tabel & $\mathbf{A}$ & Ha \\
\hline ROA & 4.574 & 1.69236 & 0.05 & Diterima \\
\hline OCF & -0.077 & 1.69236 & 0.05 & Ditolak \\
\hline SG & 5.108 & 1.69236 & 0.05 & Diterima \\
\hline TATO & 2.775 & 1.69236 & 0.05 & Diterima \\
\hline CFRS & 0.891 & 1.69236 & 0.05 & Ditolak \\
\hline CFNI & 0.067 & 1.69236 & 0.05 & Ditolak \\
\hline
\end{tabular}

Sumber: data yang diolah

Namun penolakan hipotesis alternatif Ha untuk rasio OCF, CFRS dan CFNI ini dikarenakan oleh kinerja perusahaan yang memang tidak menunjukkan perbedaan yang signifikan, pada dua tahun sesudah IPO dibanding dengan satu tahun sebelum IPO.

Hasil uji t penelitian menunjukkan ada perbedaan yang signifikan dari rasio keuangan hanya untuk ROA, SG dan TATO secara serentak, sehingga dinyatakan bahwa Ha diterima untuk rasio tersebut, hal ini konsisten dengan hasil penelitian Ikhsan (2011) yang menunjukkan bahwa pengujian secara serentak terhadap rasio keuangan ini menyatakan kinerja perusahaan ratarata lebih baik sebelum perusahaan melakukan IPO kecuali untuk operating cash flow, cash flow return on sales dan cash flow to net income. Hal ini mengindikasikan bahwa terdapat perbedaan kinerja perusahaan yang signifikan sebelum dan sesudah melakukan IPO. Artinya, jika perusahaan mencoba untuk meningkatkan kinerja operasi sebelum IPO dengan melakukan manajemen laba, maka dampak dari manajemen laba akan dirasakan pada periode pasca IPO. Selain itu juga hasil penelitian ini membuktikan bahwa kinerja perusahaan sesudah melakukan IPO cenderung menurun, hanya saja yang memiliki perbedaan yang signifikan terdapat pada rasio ROA, SG dan TATO.

Berdasarkan hasil dari uji beda t (paired-samples $t$ test) hasil penelitian pada bagian sebelumnya, maka diperoleh beberapa kesimpulan sebagai berikut:

1. Hasil pengujian kinerja keuangan untuk satu tahun sebelum dan dua tahun sesudah IPO untuk uji dengan seluruh sampel mengalami perbedaan yang signifikan jika dilakukan uji dengan menggunakan rasio ROA, SG dan TATO pada perusahaan setelah IPO.

2. Sedangkan untuk hasil pengujian kinerja keuangan untuk satu tahun sebelum dan dua tahun sesudah IPO untuk uji t dengan seluruh sampel mengalami perbedaan yang tidak signifikan jika dilakukan uji dengan menggunakan rasio OCF, CFRS dan CFNI pada perusahaan setelah IPO.

3. Ditemukan indikasi bahwa manajemen perusahaan melakukan aktivitas peningkatan kinerja dengan upaya melakukan manajemen laba (earnings 
anagement) pada periode sebelum IPO yang menjadikan salah satu penyebab kinerja setelah IPO cenderung menurun.

\section{KETERBATASAN PENELITIAN}

Keterbatasan dalam penelitian ini dapat dijabarkan sebagai berikut:

1. Masih adanya sejumlah variabel lain yang belum digunakan untuk mewakili kinerja keuangan untuk melihat perbedaan kinerja perusahaan sebelum IPO dengan sesudah IPO.

2. Objek penelitian yang terbatas dengan lebih berfokus kepada perusahaan sektor yang terdaftar di Bursa Efek Indonesia.

3. Dalam penelitian ini peneliti hanya mengunakan data sekunder, sehingga analisis data sangat tergantung pada hasil publikasi data (laporan keuangan perusahaan). Laporan keuangan sebagai data rasio punya keterbatasan karena perusahaan mempunyai metode dan kebijakan akuntansi yang berbeda sehingga sulit diperbandingkan.

4. Rentang waktu yang digunakan dalam melakukan penelitian ini terlalu sempit untuk menggambarkan keadaan yang sesungguhnya. Karena dengan rentang waktu yang singkat belum mampu memberikan gambaran yang secara terperinci dan detail.

Untuk penelitian selanjutnya disarankan :

1. Untuk penelitian selanjutnya dapat menggunakan ruang lingkup penelitian yang lebih luas yaitu dengan menambahkan dalam mengambil sektorsektor perusahaan yang terdaftar di BEI yang terdapat di Indonesia baik yang sudah go publicmaupun yang belum go public untuk dijadikan objek penelitian selanjutnya.

2. Penelitian selanjutnya dapat mempergunakan rasio keuangan lainnya dalam mengukur kinerja keuangan. Agar lebih terlihat dan komplek dalam menggambarkan kinerja perusahaan. Bisa menambahkan pengujian manajemen laba yang dilakukan untuk menilai kinerja perusahaan untuk menghasilkan data yang lebih valid.

\section{Referensi}

[1] Agustina, A. (2012). Analisis Kinerja Operasi Perusahaan Sebelum Dan Sesudah Initial Offering Public (IPO) Di Bursa Efek Indonesia. (Skripsi Fakultas Ekonomi Universitas Lampung), 1-272.

[2] Ayun, Q. (2011). Penilaian Kinerja (Performance Appraisal) Pada Karyawan Di Perusahaan, 74-88.

[3] Brahmasari.I.A, \& Suprayetno.A. (2008). Pengaruh Motivasi Kerja, Kepemimpinan Dan Budaya Organisasi Terhadap Kepuasan Kerja Karyawan Serta Dampaknya Pada Kinerja Perusahaan (Studi Kasus Pada PT. Pei Hai International Wiratama Indonesia). Jurnal Manajemen Dan Kewirausahaan, 10(1996), Pp.124-135.

[4] Bodie, Zvi, Alex Kane dan Alan J. Marcus. 2006. Investments. Terjemahan Zulaini Dalimunthe dan Budi Wibowo. Jakarta: Salemba Empat.

[5] Fahmi, I. (2014). Analisis Laporan Keuangan, Alfabeta, Bandung.

[6] Hartono, Jogiyanto. 2010. Teori Portofolio dan Analisis Investasi (Edisi 3). Yogyakarta: BPFE- Yogyakarta.

[7] Husnan, S. (2005), Dasar-dasar Teori Portofolio dan Analisis Sekuritas. 
Yogyakarta, BPFE.

[8] Ikhsan, A. E. (2011). Analisis Kinerja Perusahaan: Sebelum Dan Sesudah Initial Public Offering Di Bursa Efek Indonesia, 38-45. Jurnal Ekonom, Vol 14, No.1 Januari 2011.

[9] Jogiyanto, H.M. 2003. Teori Portofolio dan Analisis Investasi. Edisi 3. BPFE. Yogyakarta.

[10] Kusumawati, F. L, Kertahadi \& Darminto. (2014). Analisis Kinerja Keuangan Perusahaan Sebelum Dan Sesudah Initial Public Offering ( IPO ) Di Bursa Efek Indonesia ( Studi Pada Perusahaan Yang Listing Di BEI Tahun 2009), 8(2).

[11] Murhadi, Werner.R (2012). Analisis Laporan Keuangan Proyeksi Dan Valuasi Saham. Salemba Empat. Jakarta

[12] Nasir, M. dan Pamungkas Sari Ayu, 2005, “Analisis Kinerja Keuangan Perusahaan Non Perbankan Sebelum dan Sesudah Menjadi Perusahaan Publik", Media Ekonomi \& Bisnis, Vol. XVII, No. 2, Desember, pp. 3445

[13] Prasetyo.B dan Jannah,L.M (2005). Metode penelitian kuantitatif, teori dan aplikasi,PT Raja Grafindo Persada. Jakarta

[14] Prasetyo.B dan Jannah,L.M (2012). Metode penelitian kuantitatif, teori dan aplikasi,PT Raja Grafindo Persada. Jakarta

[15] Rusdin. (2008). Pasar Modal Cetakan Kedua, Bandung. Alfabeta.

[16] Sen.Y \& Safitri.L (2010). Analisis Perbedaan Kinerja Keuangan Sebelum Dan Sesudah Initial Public Offering Pada Perusahaan Go Public Di Bursa Efek Indonesia, 13(3), 1-8.

[17] Sukestiyarno (2014). Statistika Dasar.CV Andi Offset. Yogyakarta.

[18] Susilowati, F., \& Amanah, L. (2013). Analisis Kinerja Keuangan Sebelum Dan Sesudah, 2(3). Jurnal Ilmu \& Riset Akuntansi Vol. 2 No. 3 (2013)

[19] Undang-Undang Republik Indonesia Nomor 8 Tahun 1995 Tentang Pasar Modal. (1995), (8), 1-89. www.idx.co.id 